14S Critical Reflections on Latin America Series 
THIS PAGE INTENTIONALLY LEFT BLANK 


\section{Machado de Assís}

Reflections on a Brazilian Master Writer

Edited by RICHARD GRAHAM

University of Texas Press, Austin Institute of Latin American Studies

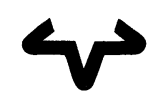


Copyright (C 1999 by the University of Texas Press

All rights reserved

Printed in the United States of America

First Edition, 1999

Requests for permission to reproduce material from this work should be sent to Permissions, University of Texas Press, P.O.

Box 7819, Austin, Texas 78713-7819

\section{Library of Congress Cataloging-in-Publication Data}

Machado de Assis : reflections on a Brazilian master writer / edited by Richard Graham. - 1st ed.

p. cm. - (Critical reflections on Latin America series)

Includes bibliographical references and index.

Contents: Dom Casmurro : realism and intentionalism revisited / John Gledson - Dom Casmurro : simulacrum and allegory / João Adolfo Hansen - Dependents play chess : political dialogues in Machado de Assis / Sidney Chalhoub - Machado in English / Daphne Patai.

ISBN 0-292-72821-2 (hard : alk. paper). — ISBN 0-292-72822-0 (pbk. : alk. paper)

1. Machado de Assis, 1839-1908. Dom Casmurro. 2. Machado de Assis, 1839-1908-Criticism and interpretation. I. Graham, Richard, 1934- . II. Series.

PQ9697.M18D636 1999

$869.3-\mathrm{dc} 21$ 